\title{
Government Agility and Management Information Systems: Study of Regional Government Financial Reports
}

\author{
Jamaluddin AHMAD ${ }^{1}$, Asdian EKAYANTI ${ }^{2}$, Nurjannah NONCI ${ }^{3}$, Muhammad Rohady RAMADHAN ${ }^{4}$
}

Received: July 21, 2020 Revised: August 23, 2020 Accepted: August 28, 2020

\begin{abstract}
This study investigates the application of management information systems to the quality of local government financial reports, especially the principle of transparency and the law of accountability, which have been measures of financial statement performance evaluation. The study was conducted in Enrekang Regency, Indonesia, which, based on the results of the examination, the Supreme Audit Board reported the status of Disclaimer, Fair with Exceptions, and Fair without Exceptions for three years each. This study used a sample of 35 respondents, finance department employees who worked on local government financial reports. Descriptive quantitative data were collected using a questionnaire instrument, then with the assistance of the Program Solution and Product Statistics (SPSS) Program, data were processed to test hypotheses. The results showed that the use of management information systems based on information and communication technology (ICT) had a significant influence on the quality of local government financial reports. The findings of this study indicate that the application of ICT-based management information systems affects the accountability and transparency of local government financial reports. This finding is reinforced by the use of the principles of government agility in the form of government apparatuses that apply responsive dexterity, flexibility agility, and competency agility.
\end{abstract}

Keywords: Government Agility, Management Information Systems, Financial Statements

JEL Classification Code: D78, O33, O38

\section{Introduction}

The best local government financial reports from the examination results of the Indonesian Supreme Audit Agency (BPK) are the 'unqualified opinion' (Agustin \& Arza, 2020).

${ }^{1}$ First Author and Corresponding Author. Associate Professor, Department of Public Administration, Social and Political Science Faculty, Muhammadiyah Sidenreng Rappang University, Indonesia [Postal Address: Jl. Angkatan 45 No.1A, Rappang, Sidenreng Rappang, Sulawesi Selatan, 91651, Indonesia]

Email: jahmadlado@yahoo.co.id

${ }^{2}$ Assistant Professor, Department of Public Administration, Social and Political Science Faculty, Muhammadiyah Sidenreng Rappang University, Indonesia. Email: aqilahasdian@gmail.com

${ }^{3}$ Associate Professor, Department of Public Administration, Social and Political Science Faculty, Muhammadiyah Sidenreng Rappang University, Indonesia. Email: noncinurjannah@yahoo.com

${ }^{4}$ Assistant Professor, Department of Public Administration, Social and Political Science Faculty, Muhammadiyah Sidenreng Rappang University, Indonesia. Email: rohady.ramadhan@gmail.com

(c) Copyright: The Author(s)

This is an Open Access article distributed under the terms of the Creative Commons Attribution Non-Commercial License (https://creativecommons.org/licenses/by-nc/4.0/) which permits unrestricted non-commercial use, distribution, and reproduction in any medium, provided the original work is properly cited.
The budget management marks this opinion in the form of the object of public scrutiny in assessing the extent to which the principles of accountability and transparency have been implementing by local governments (Agustin \& Arza, 2020; Aminah, Maisyarah, \& AlParok, 2020). Other opinions are Fair Qualification, Unusual Opinion, or Report refusing to give an opinion or not giving an opinion (Disclaimer) (Nuryati, Pratama, \& Refina, 2020). For comparison, in Malaysia, the Auditor General, who has completed the task of auditing financial statements, will issue a certificate in the form of "not eligible," "eligible," "detrimental," or "disclaimer" (Ibrahim et al., 2020). In Jordan, the modified audit opinion has not meet the requirements with an explanation paragraph, which meets the requirements, disadvantages, and disclaimers (Alkilani, Nordin, Hussin, \& Salim, 2020). Therefore, all local governments in Indonesia will try to achieve the highest opinion, that is, unqualified. The commitment of the local government to accomplish that is very high. The higher the promise made by government officials, the better and higher the effect on accountability in managing public funds (Hardiningshi, Udin, Masdjojo, \& Srimindarti, 2020). 
Local governments will publicized it on a large-scale if they get an "unqualified opinion" (Agustin \& Arza, 2020). Because to achieve this opinion requires excellent transparency and accountability. To achieve this, we need an internal control system (Dollery, Kitchen, McMillan, \& Shah, 2020). The internal control system is a computer management information system (Dollery et al., 2020). The use of computer equipment can change from traditional management to modern management for the efficiency and significance of financial statements (Jiang, 2020). Thus, the Government of Enrekang Regency, since 2016, has received the opinion "disclaimer", in 2017 it received the opinion "Fair With Exception," and in 2018, it received the opinion "Fair without Exception." For three years in a row, it was able to perform well from the lowest to the highest, with the use of computers in financial reporting. How is the implementation of management information systems so that within three years it can reach the highest opinion, and what strategies are used by local governments to accelerate the achievement of the highest opinion.

The use of financial technology, in the shape of management information system applications, and how it has developed has influenced many people, especially the use of information and communication technology (ICT) in human life (Afroz, Muhibbullah, \& Morshed, 2020). Nevertheless, the weaknesses of the state of skills and technological innovation, leading to in-depth knowledge, scholarly output, and creative output (Alibekova, Medeni, Panzabekova, \& Mussayeva, 2020) still occur. Therefore, the importance of management integrating finance and business through information technology that can be implemented through financial management software (Jiang, 2020). The use of regional financial information systems is more positive and significant to the accountability of local financial reporting (Aminah et al., 2020). Application of information technology for commercial network systems is critical to modern society (Jiang, 2020). With information technology, economic, statistical data are easily available, making it more accessible in the decision-making process (Ehalaiye, Redmayne, \& Laswad, 2020). Thus, the use of information technology applications in local government financial reports is better, more transparent, and accountable.

By making conceptual recommendations, the agileadaptive approach, transparency policy, and citizen voluntary cooperation are important factors (Moon, 2020). Digital transformation is a strategic imperative for government (Gong, Yang, \& Shi, 2020). To achieve the highest opinion in the management of the use of the budget, a very good management information system is needed. Agility governance is governance with a focus on the spread of technology in work processes and the process of organizational change (Dittrich, Pries-Heje, \& HjortMadsen, 2005) for the better.

\section{Literature Review}

The concept of agility is to move quickly in an intelligent way (Dittrich et al., 2005), the ability to respond to unexpected changes with rapid response and profitability (Hassan Ismail, 2020), and the ability to adapt or respond to external stimuli effectively and efficiently (Paul, Jena, \& Sahoo, 2020). Agility is the ability to continuously adjust the strategic direction as a function of strategic ambition and changing circumstances (Khan, Soundararajan, \& Shoham, 2020). Fundamentals of agile technology consist of three main parts, namely, responsiveness, flexibility, and competence (Ezcan, Goulding, \& Arif, 2020).

Diffusion of responsive agility consists of sense, understanding and anticipating changes and risks in the environment, a direct reaction to changes and demands, and recovery from change. It is the ability to feel changes in the background and realize internal capabilities to serve the new opportunities presented (Pereira, Budhwar, Temouri, Malik, \& Tarba, 2020). It is also the ability to appreciate direct reactions to technology and its influence on change (Ezcan et al., 2020), and responses from certain interest groups (Doz, Kosonen, \& Virtanen, 2018). As well as recovery from the change, it is an organizational process that seeks to return to standards (Ezcan et al., 2020). Thus, responsive skill is the ability to anticipate changes in the environment, react quickly as opportunities, and recover from change.

The diffusion of agility flexibility consists of human resources flexibility, information technology flexibility, and process flexibility. Human resource flexibility includes quickly learning new procedures and solving specific problems (Moon, 2020), including rapidly learning from mistakes (Pfeffermann, 2020), quickly learning how to apply changes to their standard operating procedures. The ability to change positions of responsibility for standardization (Idowu, Vries, Mijatovic, \& Choi, 2020) is different, and change habits and patterns of behaviour (Trost, 2020). Information technology flexibility includes the development of information technology infrastructure design (Cleveland \& Cleveland, 2020; Helms \& Nixon, 2010) so that it can handle changes in the number of users, workloads, and transactions. Development of information technology infrastructure that is modern and can be used easily (Zykov \& Singh, 2020). Fundamental reforms in the structure and evolution of information technology (Helms \& Nixon, 2010). Finally, process flexibility consists of developing various solutions (Çağlar Kalkan \& Aydın, 2020), availability of mobility (Pfeffermann, 2020), and uniformity that is easy with change (Hassan Ismail, 2020).

Diffusion of competence agility consists of leadership, management of change process, and business strategy development. Leadership is motivating individuals in organizations (Kalkan, Altınay Aksal, Altınay Gazi, Atasoy, 
\& Dağl1, 2020), as well as cultural integration and knowledge transfer (Pereira et al., 2020) in supporting the implementation of new technologies. The management of change process is a reengineering process to maintain stability (Trost, 2020), provide services and support (Ezcan et al., 2020; Trost, 2020), and communication development (Bourjade, Cochet, Molesti, \& Guidetti, 2020; Idowu et al., 2020). Finally, business strategy development is the development of information technology strategies or information systems (Pfeffermann, 2020), HR strategy development, and training strategy development (Ezcan et al., 2020).

The agility government is a government that implements information and communication technology in building responsiveness, flexibility, and competence to deal with environmental changes that are full of uncertainty. The information technology that is intending is the application of management information systems (Dollery et al., 2020), in the form of software applications used in financial statement management. Combined communication and management information technology (Zykov \& Singh, 2020).

Some concepts related to agility governance are; e-governance and e-government. E-governance is a means of delivering government information and services by the government to the public in the form of information and communication technology applications (Sisodia et al., 2020). Whereas e-government is an electronic government service, aspects related to transaction transparency and security play a fundamental role in building trust in the services provided (Geneiatakis et al., 2020). Agility governance still uses e-governance and e-government, but it always focuses on the ability to move quickly and deftly towards a better direction in an intelligent way.

\section{Research Methods and Materials}

This research is included in the type of quantitative descriptive analysis to get a picture of the object under study. The purpose is in the form of data that is described in accordance with the conditions in the field, then analyzed based on the grand theory used as an analysis tool. The population and cover of the study were 35 respondents who served in the financial reporting of the Enrekang district government.
Data collection techniques use observation, interviews, questionnaires, and study documentation. Data is processed using simple regression, namely: $\mathrm{Y}^{\prime}=\mathrm{a}+\mathrm{bX}$. The processing of using simple regression in predicting the calculated value can be measured from a value that is very appropriate. According to statistics, this measure is carried out by finding the value of $F$, the value of $t$, and the value of the coefficient of determination. The statistical test $\mathrm{f}$ is used to indicate whether all the independent variables entered in the model have a joint influence on the dependent variable. Statistical value $\mathrm{F}$ is called significant if the $\mathrm{f}$-count $<0.05$, or if the f-count value $>$ f-table. The t-test statistic shows how far the influence of one explanatory/independent variable individually explains the variation of the dependent variable. The value of $t$ is declared significant if the calculation results are in the critical area of the hypothesis rejected, and declared not significant if the hypothesis is accepted. Or by comparing the significance level of $t$ with $0.05(\alpha=5 \%)$ or comparing between $t$ arithmetic with $t$-table. If the significance level of $\mathrm{t}$-count $<0.05$ or if the value of the t-statistic result is greater than the t-table value, then the hypothesis is accepted.

\section{Results and Discussion}

\subsection{Results}

Several indicators are: measured access capability, service portals, supporting information processing organizations, and infrastructure. The management information system has an application portal that is used for local government financial reports.

From Table 1, it can be seen that, of the four indicators that influence the regional financial management information system, the most dominant is the "infrastructure" indicator of information technology infrastructure, with an average percentage of $57.2 \%$. At the same time, the lowest index is the "access" indicator on the portal application, with an average rate of $53.8 \%$, obtaining an average percentage of $58 \%$, which is categorizing as less good.

Based on the results of the research on the quality of local government budget reports, the quality level of local government can be well known, the report on budget use is explained in Table 2:

Table 1: Recapitulation of Respondents' Responses About Regional Financial Management Information Systems

\begin{tabular}{|l|l|c|}
\hline No & \multicolumn{1}{|c|}{ Management information System Regional Finance } & Percentage (\%) \\
\hline 1 & Access & 53,80 \\
\hline 2 & Public service portal & 57,20 \\
\hline 3 & Information processing organization supporting organizations & 54,20 \\
\hline 4 & Infrastructure & 66,80 \\
\hline
\end{tabular}


Table 2: Recapitulation of Respondents' Responses about the Quality of Regional Government Financial Statements

\begin{tabular}{|l|l|c|}
\hline No & \multicolumn{1}{|c|}{ Quality of Regional Government Financial Statements } & Percentage (\%) \\
\hline 1 & Relevant & 54,20 \\
\hline 2 & Reliable & 70,20 \\
\hline 3 & Can be compared & 53,80 \\
\hline 4 & Can be understood & 69,20 \\
\hline
\end{tabular}

Table 3: Recapitulation of Respondents' Responses About Factors Affecting the Quality of Local Government Financial Statements

\begin{tabular}{|l|l|c|}
\hline No & \multicolumn{1}{|c|}{ Indicator } & Percentage (\%) \\
\hline 1 & Understanding of government accounting standards & 57,20 \\
\hline 2 & The role of internal audit & 54,20 \\
\hline 3 & Human resource competence & 66,80 \\
\hline
\end{tabular}

Tabel 4: Model Summary

\begin{tabular}{|l|c|c|c|c|}
\hline Model & $\mathbf{R}$ & $\mathbf{R}$ Square & Adjusted R Square & Std. Error of the Estimate \\
\hline 1 & $.882^{\mathrm{a}}$ & .778 & .772 & 1.276 \\
\hline
\end{tabular}

a. Predictors: (Constant), Management Information System (X)

b. Dependent Variable: Transparency and accountability Report on the use of Local Government budget ( $Y$ )

In Table 2, of the four indicators that influence the quality of the financial statements of local governments, the most dominant is the "reliable" indicator, with an average percentage of $70.2 \%$. While the lowest index is the "comparable" indicator with an average percentage of $53.8 \%$, the result is a level of transparency and accountability of reports on the use of local government budgets obtaining an average percentage of $61.9 \%$, which falls into both categories.

Factors affecting transparency and accountability of local government budget use reports are explained in Table 3:

From Table 3, it can be seen that there are indicators to understand government accounting standards, the role of internal audit, and the competence of the state civil apparatus handling the reporting. And the factors that influence the transparency and accountability of reports on the use of local government budgets. Of the three indicators, the most dominant factor affecting the quality of local government financial reports is an indicator of understanding government accounting standards (SAP) with an average percentage of $57.2 \%$. In contrast, the lowest index is the role of internal audit with an average rate of $54.2 \%$; when combining the part of internal audit with human resource competence in the factors that affect the quality of local government financial reports, it obtains an average percentage of $59.4 \%$, which is categorized as not good.
Table 4 model summary explains the value of $\mathrm{R}$ square or the percentage contribution. The influences of independent variables on the dependent variable is 0.778 , which is also called the coefficient of determination. This implies that the impact of the independent variable (regional financial management information system) on the dependent variable (transparency and accountability report on the use of local government budget (Y) is $77.8 \%$. As for other factors not examined in this study.

The results obtained from Table 5 show that there is a significance between variable $\mathrm{X}$ and variable $\mathrm{Y}$. Management information system and transparency and accountability report on the use of local government budget. From the calculation above, it can be seen that $\mathrm{F}$ arithmetic $=115,945>$ $\mathrm{F}$ table $=4.12$ with a significant level of probability 0,000 $<0.005$, then the regression model can be used to predict the variable quality of local government financial statements.

The table above explains the variables of management information system $(\mathrm{X})$ the $\mathrm{t}$-count $=10.768$, which will be used in conducting the t-test, namely, partially testing the effect of variable $\mathrm{X}$ on variable $\mathrm{Y}$ (transparency and accountability report on the use of local government budget).

Based on the coefficient table in Table 6, the constant value of "a" is 6.856, while the regression coefficient of the $\mathrm{X}$ variable " $\mathrm{b}$ " is 0.909 . The linear regression equation is simple, namely, $\mathrm{Y}^{`}=\mathrm{a}+\mathrm{b}, \mathrm{X}$ to: $\mathrm{Y}^{`}=6.856+0.909 \mathrm{X}$. The 
Tabel 5: ANOVA ${ }^{b}$

\begin{tabular}{|l|l|c|c|c|c|c|}
\hline \multicolumn{2}{|l|}{ Model } & $\begin{array}{c}\text { Sum of } \\
\text { Squares }\end{array}$ & df & Mean Square & F ig. \\
\hline \multirow{3}{*}{1} & Regression & 188.694 & 1 & 188.694 & 115.945 & $.000^{a}$ \\
\cline { 2 - 6 } & Residual & 53.706 & 33 & 1.627 & & \\
\cline { 2 - 6 } & Total & 242.400 & 34 & & \\
\hline \\
a. Predictors: (Constant), Management Information System (X) \\
b. Dependent Variable: Transparency and accountability Report on the use of Local Government budget (Y) \\
\hline
\end{tabular}

Tabel 6: Coefficients ${ }^{a}$

\begin{tabular}{|c|c|c|c|c|c|c|}
\hline \multirow{2}{*}{\multicolumn{2}{|c|}{ Model }} & \multicolumn{2}{|c|}{ Unstandardized Coefficients } & \multirow{2}{*}{\begin{tabular}{|c} 
Standardized Coefficients \\
Beta
\end{tabular}} & \multirow{2}{*}{$\mathbf{t}$} & \multirow{2}{*}{ Sig. } \\
\hline & & B & Std. Error & & & \\
\hline \multirow[t]{2}{*}{1} & (Constant) & 6.856 & 1.000 & & 6.851 & .000 \\
\hline & $\begin{array}{l}\text { Regional Financial Management } \\
\text { Information System (X) }\end{array}$ & .909 & .084 & .882 & 10.768 & .000 \\
\hline
\end{tabular}

coefficient " $b$ " is called the regression direction coefficient and states the average change in the variable $\mathrm{Y}$ for each change in variable $X$ by one unit. This change is an increase if $b$ is positive and decreases if $b$ is negative. From the simple linear regression equation above, it can be explained that the constant of 6.856 states that, if there is no value of the value of $\mathrm{X}=0$, then the quality of the local government financial statements becomes 6.856 or equal to the constant value. The regression coefficient $\mathrm{X}$ of 0.909 states that, for each addition of 1 value of the regional financial management information system, the value of the quality of the financial statements of the local government increases by 0.909 so that it becomes better.

Likewise, the T-test is used to find out whether the management information system significantly affects the transparency and accountability of local government budget use reports. The test uses a significance level of $5 \%$ or 0.05 and on two sides (two tiled). The value of $\mathrm{t}$ arithmetic variable financial management information system $(\mathrm{X})$ can be obtained from the output table Coefficients, $\mathrm{t}$-count $=$ 10.768. T table value can be obtained from the statistical table, $\mathrm{t}$ table with a significance of 0.05 and degrees of freedom $(\mathrm{df})=\mathrm{n}-2$ or $35-2=33$, then obtained for t table value of $=3.356$. The results of SPSS data processing, show $\mathrm{t}$ arithmetic $>\mathrm{t}$ table on the human resource variable $(\mathrm{X})$ or $10.768>3.356$. So it can be concluded that the management information system $(\mathrm{X})$ has a significant effect on the transparency and accountability of local government budget use reports.

\subsection{Discussion}

The application of management information system application in Table 1 shows an average level less than good with a value of $58 \%$. The ease of "access" still dominates the low answers, following the "public service portal," even though information technology infrastructure is already available. In these conditions, flexibility should be quickly implemented by learning new procedures (Moon, 2020), including fast learning from mistakes (Pfeffermann, 2020). Not easily accessible means the application of management information systems is something new for managers of local government financial reports.

This condition has an impact on the transparency and accountability of reports on the use of local budgets, in Table 2 shows that $70.2 \%$ are in the "reliable" category, and the "understandable" category is $69.2 \%$. This indicates that information technology can be implemented through financial management software (Jiang, 2020). Although in terms of the category "relevance" and "comparability" still needs to be improved. Financial, statistical data still need to be enhanced for decision making (Ehalaiye et al., 2020). The aim is that regional government financial reports become better, more transparent, and accountable.

The factors that affect the quality of financial statements according to Table 3 are the level of understanding of government accounting standards of $57.2 \%$. The role of internal audit is $54.2 \%$. Human resource competence is $66.8 \%$. Knowledge of accounting standards is related to 
human resource flexibility. Quickly learn new procedures (Moon, 2020), adjust to standardization (Idowu et al., 2020), as well as information technology (Cleveland \& Cleveland, 2020; Helms \& Nixon, 2010). The agility of human resources on information technology and the innovation process is the primary key in influencing the quality of the financial statements of local governments. Knowledge can improve organizational innovation (Muafi, 2020). By increasing awareness of information, communication technology can improve financial report quality innovation.

The results of statistical tests found that the management information system $(\mathrm{x})$ has a significant effect on the transparency and accountability of reports on the use of local government budgets (y). So, not only responsiveness and flexible agility are needed, but also the agility of government management competencies. Leadership agility (Kalkan et al., 2020) to motivate employees, so they want to change and innovate is needed. Leadership motivates subordinates to cultivate knowledge (Pereira et al., 2020) as a means of being responsive to changes in the external environment. Likewise, through leadership agility, management of change processes can take place. Even though the management information system based on application technology is included in the new category, if the leadership does not have the agility in implementing the process of management change, transparency and accountability of reports on the use of local government budgets will be affected.

Therefore, agility governance, which is characterized by responsiveness agility, flexibility agility, and competence agility, is an alternative to increasing the ability of local governments to provide public services to the community. Specifically, services related to the use of information technology on the quality of local government financial reports. The agility government is a government that implements information and communication technology in building responsiveness, flexibility, and competence to deal with environmental changes that are full of uncertainty.

\section{Conclusions}

The implementation of management information systems shows a reduced level, especially in the last three years, at Enrekang Regency, Indonesia. The management information system application already has excellent facilities and infrastructure, but is still lacking in the ease of "access" and "public service portals. The results of the processed data show that management information systems have a significant effect on transparency and accountability. Therefore, the government regions need to implement good governance to respond to environmental changes that are full of uncertainties, especially related to the opinion of financial statements based on the assessment of the Supreme Audit Board.
The agility government is a government that implements information and communication technology in building responsiveness, flexibility, and competence to deal with environmental changes that are full of uncertainty. Governments must implement responsiveness, agility flexibility, and competence agility.

\section{References}

Afroz, R., Muhibbullah, M., \& Morshed, M. N. (2020). Impact of Information and Communication Technology on Economic Growth and Population Health in Malaysia. Journal of Asian Finance, Economics and Business, 7(4), 155-162. https://doi. org/10.13106/jafeb.2020.vol7.no4.155

Agustin, H., \& Arza, F. I. (2020). Potrait of Accountability and Transparency in Local Budget Management by the Regional Government in West Sumatera Province, Indonesia: An Anomaly in Digital Era. In: Proceedings of the 4th Padang International Conference on Education, Economics, Business and Accounting (PICEEBA-2 2019) (Vol. 124, pp. 154166). Paris, France: Atlantis Press. https://doi.org/10.2991/ aebmr.k.200305.064

Alibekova, G., Medeni, T., Panzabekova, A., \& Mussayeva, D. (2020). Digital Transformation Enablers and Barriers in the Economy of Kazakhstan. Journal of Asian Finance, Economics and Business, 7(7), 565-575. https://doi.org/10.13106/ jafeb.2020.vol7.no7.565

Alkilani, S. Z., Nordin, W., Hussin, W., \& Salim, B. (2020). The Relationship between the Characteristics of a Risk Management Committee and the Issuance of a Modified Audit Opinion in the Jordanian Context. Asian Journal of Accounting and Finance, 2(2), 52-73.

Aminah, S., Maisyarah, N. D., \& AlParok. (2020). Regional Financial Information Systems Effect on Sarolangun Local Government Financial Transparency and Accountability of Financial Report. In: Proceedings of the International Conference on Public Administration, Policy and Governance (ICPAPG 2019) (Vol. 125, pp. 35-42). Paris, France: Atlantis Press. https://doi.org/10.2991/aebmr.k.200305.178

Bourjade, M., Cochet, H., Molesti, S., \& Guidetti, M. (2020). Is Conceptual Diversity an Advantage for Scientific Inquiry? A Case Study on the Concept of 'Gesture' in Comparative Psychology. Integrative Psychological and Behavioral Science. https://doi.org/10.1007/s12124-020-09516-5

Çağlar Kalkan, M. B., \& Aydın, K. (2020). The role of 4PL provider as a mediation and supply chain agility. Modern Supply Chain Research and Applications, 2(2), 99-111. https://doi. org/10.1108/MSCRA-09-2019-0019

Cleveland, M., \& Cleveland, S. (2020). Culturally Agile Leadership. International Journal of Public and Private Perspectives on Healthcare, Culture, and the Environment, 4(1), 1-9. https:// doi.org/10.4018/IJPPPHCE.2020010101

Dittrich, Y., Pries-Heje, J., \& Hjort-Madsen, K. (2005). How to Make Government Agile to Cope with Organizational Change. 
In: Business Agility and Information Technology Diffusion (Vol. 180, pp. 333-351). Boston, MA: Kluwer Academic Publishers. https://doi.org/10.1007/0-387-25590-7_21

Dollery, B., Kitchen, H., McMillan, M., \& Shah, A. (2020). Local Public, Fiscal and Financial Governance. Local Public, Fiscal and Financial Governance. Cham, Switzerland: Springer International Publishing. https://doi.org/10.1007/978-3-030$36725-1$

Doz, Y., Kosonen, M., \& Virtanen, P. (2018). Strategically Agile Government. In Global Encyclopedia of Public Administration, Public Policy, and Governance (pp. 1-12). Cham, Switzerland: Springer International Publishing. https://doi.org/10.1007/9783-319-31816-5 3554-1

Ehalaiye, D., Redmayne, N. B., \& Laswad, F. (2020). Does accounting information contribute to a better understanding of public assets management? The case of local government infrastructural assets. Public Money \& Management, 1-11. https://doi.org/10.1080/09540962.2020.1719669

Ezcan, V., Goulding, J. S., \& Arif, M. (2020). Redefining ICT embeddedness in the construction industry: maximizing technology diffusion capabilities to support agility. Building Research \& Information, 1-23. https://doi.org/10.1080/096132 18.2019.1709786

Geneiatakis, D., Soupionis, Y., Steri, G., Kounelis, I., Neisse, R., \& Nai-Fovino, I. (2020). Blockchain Performance Analysis for Supporting Cross-Border E-Government Services. IEEE Transactions on Engineering Management, 1-13. https://doi. org/10.1109/TEM.2020.2979325

Gong, Y., Yang, J., \& Shi, X. (2020). Towards a comprehensive understanding of digital transformation in government: Analysis of flexibility and enterprise architecture. Government Information Quarterly, 37(3), 101487. https://doi.org/10.1016/j. giq.2020.101487

Hardiningshi, P., Udin, U., Masdjojo, G. N., \& Srimindarti, C. (2020). Does Competency, Commitment, and Internal Control Influence Accountability? Journal of Asian Finance, Economics and Business, 7(4), 223-233. https://doi.org/10.13106/ jafeb.2020.vol7.no4.223

Hassan Ismail, N. A.-A. (2020). The Impact of Organizational Intelligence on Organizational Agility : An Empirical study in Syrian Private Banks. Human Resource Management Academic Research Society, 10(2), 465-483.

Helms, M. M., \& Nixon, J. (2010). Exploring SWOT analysis where are we now? Journal of Strategy and Management, 3(3), 215-251. https://doi.org/10.1108/17554251011064837

Ibrahim, M., Engku Ali, E., Syed Ismail, S., \& Bidin, Z. (2020). Qualified Audit Reports of Local Authorities in the Northern States of Malaysia. Malaysian Management Journal, 8(2), 7786. Retrieved from http://e-journal.uum.edu.my/index.php/ $\mathrm{mmj} /$ article/view/8762
Idowu, S. O., Vries, H. J., Mijatovic, I., \& Choi, D. (2020). Sustainable Development. In: S. O. Idowu, H. J. de Vries, I. Mijatovic, \& D. Choi (Eds.), Sustainable Development (Vol. 45). Cham, Switzerland: Springer International Publishing. https://doi.org/10.1007/978-3-030-28715-3

Jiang, X. (2020). Analysis of Information Technology Application in the Financial Management of Enterprises. Journal of Physics: Conference Series, 1533, 022047. https://doi. org/10.1088/1742-6596/1533/2/022047

Kalkan, Ü., Altınay Aksal, F., Altınay Gazi, Z., Atasoy, R., \& Dağlı, G. (2020). The Relationship Between School Administrators' Leadership Styles, School Culture, and Organizational Image. SAGE Open, 10(1), 215824402090208. https://doi. org/10.1177/2158244020902081

Khan, Z., Soundararajan, V., \& Shoham, A. (2020). Global postmerger agility, transactive memory systems and human resource management practices. Human Resource Management Review, 30(1), 100697. https://doi.org/10.1016/j.hrmr.2019.100697

Moon, M. J. (2020). Fighting COVID-19 with Agility, Transparency, and Participation: Wicked Policy Problems and New Governance Challenges. Public Administration Review, 80(4), 651-656. https://doi.org/10.1111/puar.13214

Muafi, M. (2020). A Nexus among Strategic Orientation, Social Network, Knowledge Sharing, Organizational Innovation, and MSMEs Performance. Journal of Asian Finance, Economics and Business, 7(6), 327-338. https://doi.org/10.13106/ jafeb.2020.vol7.no6.327

Nuryati, T., Pratama, B., \& Refina, P. (2020). Improving the Quality of Financial Reports by Implementing SIMAK-BMN in KPURI. In: Proceedings of the Annual International Conference on Accounting Research (AICAR 2019) (Vol. 127, pp. 157161). Paris, France: Atlantis Press. https://doi.org/10.2991/ aebmr.k.200309.035

Paul, M., Jena, L. K., \& Sahoo, K. (2020). Workplace Spirituality and Workforce Agility: A Psychological Exploration Among Teaching Professionals. Journal of Religion and Health, 59(1), 135-153. https://doi.org/10.1007/s10943-019-00918-3

Pereira, V., Budhwar, P., Temouri, Y., Malik, A., \& Tarba, S. (2020). Investigating Investments in agility strategies in overcoming the global financial crisis - The case of Indian IT/BPO offshoring firms. Journal of International Management, 100738. https:// doi.org/10.1016/j.intman.2020.100738

Pfeffermann, N. (2020). New Leadership in Strategy and Communication. In: N. Pfeffermann (Ed.), New Leadership in Strategy and Communication. Cham, Switzerland: Springer International Publishing. https://doi.org/10.1007/978-3-03019681-3

Sisodia, D. S., Bhandari, S., Reddy, N. K., \& Pujahari, A. (2020). A Comparative Performance Study of Machine Learning Algorithms for Sentiment Analysis of Movie Viewers Using Open Reviews. In: M. Pant, T. K. Sharma, S. Basterrech, \& C. Banerjee (Eds.), Performance and its Applications of 
Integrated Systems Management in Software Engineering (pp. 107-117). Singapore: Springer. https://doi.org/10.1007/978981-13-8253-6

Trost, A. (2020). Human Resources Strategies. Human Resources Strategies. Cham, Switzerland: Springer International Publishing. https://doi.org/10.1007/978-3-030-30592-5
Zykov, S. V., \& Singh, A. (2020). Agile Enterprise Engineering: Smart Application of Human Factors. Agile Enterprise Engineering: Smart Application of Human Factors (Vol. 175). Cham, Switzerland: Springer International Publishing. https:// doi.org/10.1007/978-3-030-40989-0 